God, Time, and Knowledge 
Cornell Studies in the Philosophy of Religion

EDITED BY WILLIAM P. ALSTON

God, Time, and Knowledge

by William Hasker

The Nature of God: An Inquiry into Divine Attributes

by Edward R. Wierenga 


\section{William Hasker}

God, Time, and
Knowledge

Cornell University Press, Ithaca and London 
All rights reserved. Except for brief quotations in a review, this book, or parts thereof, must not be reproduced in any form without permission in writing from the publisher. For information, address Cornell University Press, I 24 Roberts Place, Ithaca, New York I4850.

First published 1989 by Cornell University Press.

International Standard Book Number 0-80 I 4-224 I-8 Library of Congress Catalog Card Number 88-43294 Printed in the United States of America Librarians: Library of Congress cataloging information appears on the last page of the book.

The paper in this book is acid-free and meets the guidelines for permanence and durability of the Committee on Production Guidelines for Book Longevity of the Council on Library Resources.

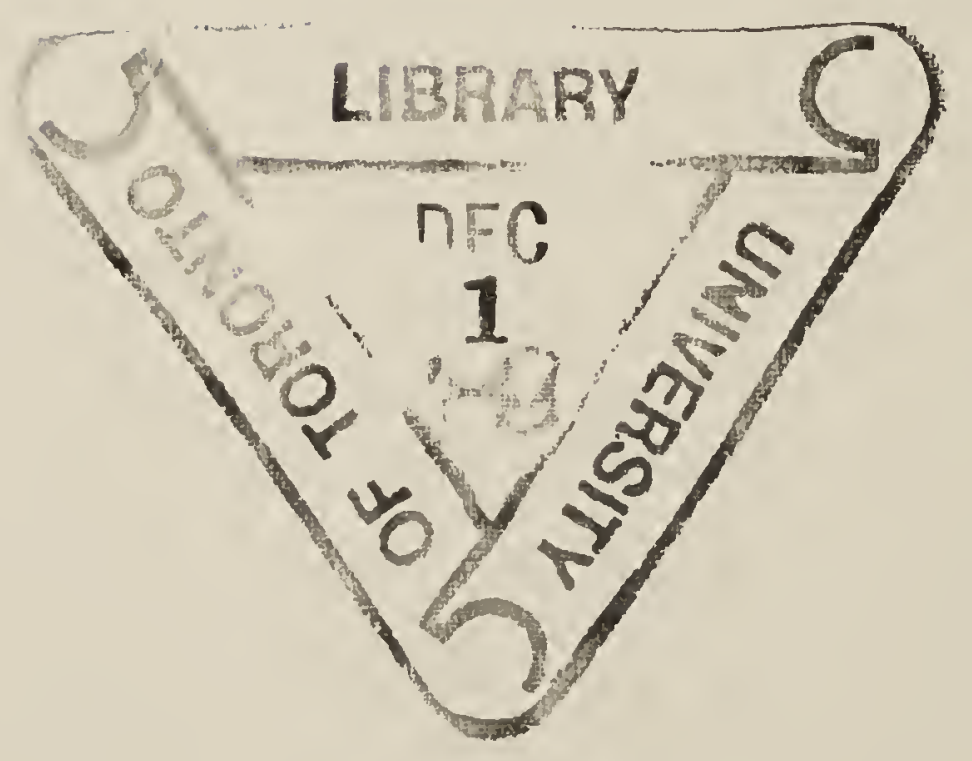


dedicated to Robert and Kevin 
Digitized by the Internet Archive in 2019 with funding from The Arcadia Fund 